\title{
Emerging Environmental Ethics for Living with Novel Fire Regimes in the Blue Ridge Mountains
}

\author{
Cynthia T. Fowler ${ }^{1^{*}}$ \\ ${ }^{1}$ Department of Sociology and Anthropology, Wofford College, Spartanburg, SC, USA. \\ *fowlerct@wofford.edu
}

\begin{abstract}
This article focuses on anthropogenic fire as a form of disturbance that is having an unusually strong influence on landscapes in the Blue Ridge Physiographic Province of the Southern Appalachian Mountains. One series of significant disturbance incidents was the Blue Ridge Complex, which was a dense cluster of wildfires that occurred during the fall of 2016. This article contains ethnographic information that I collected when the Blue Ridge Complex fires were burning and thereafter through the use of participant observation at community gatherings, land management events, and recreational activities. I have also conducted one-on-one interviews with residents of the fire-affected region, land managers, and firefighters. In community gatherings and in conversations with others, people living in the Blue Ridge Complex zone produced a collective ethical assemblage for living in a burning and burned landscape. The spatial and temporal patterns of burning in the fall of 2016 were so distinct from previous years that they may have redefined the Blue Ridge bioregion's fire regimes. The proliferation of wildfires during the fall of 2016 also generated occasions for people to formulate their values related to one another, to their nonhuman co-residents, to fire, and to the overall mountainous landscape.
\end{abstract}

Received July 11, 2017

OPEN ӘACCESS

Accepted February 12, 2018

DOI 10.14237/ebl.9.1.2018.1049

Keywords Fire, Ethics, Pisgah National Forest, Nantahala National Forest, Blue Ridge Mountains, Southern Appalachia,

Copyright (C) 2018 by the author(s); licensee Society of Ethnobiology. This is an open-access article distributed under the terms of the Creative Commons Attribution-NonCommercial 4.0 International Public License (https://creativecommons.org/licenses/by-nc/4.0), which permits non-commercial use, distribution, and reproduction in any medium, provided the original author and source are credited.

\section{Introduction}

In a context of long-term ecological change fostered by multiple drivers of disturbance, people have been a key agent of change in the Southern Appalachian Mountains for at least 12,000 years (Delcourt and Delcourt 2004). Throughout the history of occupation, human actions together with environmental events (Vayda 2009) have constituted the myriad disturbance management regimes (Coughlan 2016) that have been shaping Southern Appalachian landscapes. Environmental events that are typical forms of disturbance in the region are windthrow, rain, ice, drought, fungi (e.g., Chestnut blight, Beech bark disease), and insects (e.g., the Hemlock woolly adelgid, balsam woolly adelgid, Emerald Ash borer, pine beetle) whose impacts cause significant ecosystem change. The most temporally persistent and impactful types of human actions in the region have been harvesting, burning, logging, grazing, and converting habitat from forested terrain to non-forested residential, commercial, and recreational sites. Disturbance management regimes in this region include the concrete actions performed by a succession of societies beginning with huntergatherers and horticulturalists in the Prehistoric era, followed by Euro-American settlers in Colonial times, and then settler descendants as well as public and private land managers in the current era (Fowler and Konopik 2007). Disturbance management regimes intervene in species composition and spatial structure (Cox et al. 2016) in ways that influence ecosystem processes-such as succession, water circulation, carbon storage, and soil erosion-and functionincluding their protective, productive, and social roles.

This article focuses on anthropogenic fire as a form of disturbance that, in the fall of 2016, had an unusually strong influence on landscapes in the Blue Ridge Physiographic Province of the Southern Appalachian Mountains. The fall 2016 wildfire season caused immediate environmental changes and will likely have long-term effects as well. A spatially and temporally dense cluster of wildfires called the "Blue 
Ridge Complex"1 also fostered a reconfiguration of values among communities in the mountains of Western North Carolina (WNC), northwestern South Carolina, and the portion of North Georgia where the Rock Mountain Fire burned. More than 20 wildfires burned approximately 100,000 acres of public and private land in WNC between October and December of 20162. Fourteen of the Blue Ridge Complex fires were human-caused (InciWeb 2018). Lightning is suspected of igniting the Boteler fire on October 25, 2016, but the cause is officially still unknown (Chávez 2016; Hendershot 2017; InciWeb 2018) as are the causes of an additional six of the 20 wildfires (InciWeb 2018).

The Blue Ridge Complex comprised the especially active fall 2016 fire season, and emerged at a time when many people living in the Blue Ridge Mountains experienced novel fire behavior in familiar landscapes. The spatial and temporal patterns of burning in the fall of 2016 were so distinct from previous years that they may have redefined the Blue Ridge bioregion's fire regimes. As they witnessed their landscapes burning during the fires and observed the postfire landscapes, residents were provoked into thinking and talking about their morals related to one another, to their nonhuman co-residents, to fire, and to the overall mountainous environment. For about two months, while Blue Ridge residents were enmeshed in a burning landscape, they were also negotiating their ethical lives. In other words, the wildfires affected "aspects of people's experiences and perceptions that they...draw on in the process of making ethical evaluations and decisions, whether consciously or not" (Keane 2015:27 quoted in Weiss 2017:2).

The dramatic change in the Blue Ridge Province's fire regime occurred in spaces that have been undergoing significant social changes, with notable alterations in demographics, policies, and land use. Ongoing environmental changes involve shifting annual and seasonal precipitation and temperature. Shifts in demography and mobility are forces of change in WNC's disturbance regimes as is evident in the ignition sites of the fall 2016 wildfire many of which were on or near roadsides. The fire management crews on the 2016 wildfires did not spend all of their time deep inside remote parts of these biodiverse, temperate forests, but instead exhausted their resources protecting "human assets" in the Wildland Urban Interface (WUI) along the boundaries of the National Forests. More and more second-home owners, retirees, and homesteaders have been cutting driveways, building homes, sculpting naturalistic landscapes, rearranging fuels, and disturbing forests in the Wildland Urban Interface. The National Fire Protection Association's Firewise program is responding to the increase in population densities in the Wildland Urban Interface by organizing neighborhood groups to install defensible space around their homes and to use flame resistant building and landscaping materials. Changing disturbance regimes along the edges of the National Forests in WNC causes changes to the composition, structure, and function of ecosystems within the National Forests' boundaries. Alterations in fire regimes accompany shifts in human communities and in ecosystems. The unprecedented fall 2016 fire season is a case in point.

\section{Collective Values Co-Emerge with Novel Fire Regimes}

Much of the land burned by the fall 2016 humanignited fires in WNC was within the Nantahala and Pisgah National Forests, which together occupy 1.31 million acres or $22 \%$ of WNC. When the forested slopes and valleys of the Southern Appalachians were burning in the fall of 2016, the actions that land managers took in response to the fires had immediate and long-term impacts on ecosystems. Wildland firefighters were attacking fires by constructing firebreaks with small hand tools and large bulldozers, dropping retardant and water from helicopters, and burning off fuels in the fires' paths using ground and aerial ignition techniques. While the first responders were local salaried and volunteer firefighters, as the fires grew beyond their capacity to control, fire management was turned over to federal Incident Management Teams (IMTs); namely the Southern Area Type 1 Blue Team, Red Team, and Gold Team; the Sierra Front Type 3 Team; and the Central Montana Type 2 Team. The IMTs - at the top of the massive federal fire management hierarchycontrolled operations and coordinated their activities with state agencies and local firefighters and law enforcers. At the same time, wildland firefighters were engaging with people outside of their institutional boundaries by hosting community meetings, receiving fanfare from schoolchildren and donations from volunteers, posting on social media, and providing news to journalists. Other parties who involved themselves in fire management operations are 
residents of fire-affected areas, volunteers who donated supplies and their time to assisting fire crews, NGO stakeholders, and journalists.

The United States federal government is increasingly building outreach into the standard modes of operation for land and fire management agencies. The 2012 planning rule shift to "collaboration throughout the planning process" (USDA Forest Service 2018) partially explains the multiple public meetings and online comment periods that have been part of the ongoing NantahalaPisgah Forest Plan development process. Across the region, the IMTs who were managing the various wildfires in the Blue Ridge Complex hosted community meetings in local gathering places. The IMTs on the Ferebee, Tellico, Boteler, Clear Creek, Pinnacle, Party Rock, and additional wildfires used the community meetings to inform local people about wildfire developments and fire management efforts. These community meetings were productive fora where residents of affected communities expressed their understandings of the roles of fire in their landscapes. At these meetings, community members discussed their values related to fire, the land, and a variety of other dimensions of their ethical lives.

An illustrative community gathering was one called by the Southern Area Red Team (i.e., Incident Management Team), which was the fire crew who managed the Nantahala Branch Complex ${ }^{3}$. On November 13, 2016, the Southern Area Red Team held a community meeting for the Tellico and Ferebee Fires. More than 200 residents of the fireaffected area gathered in the Southwestern Community College gymnasium. Mike Dueitt, the Incident Commander for the Southern Area Red Team, opened the meeting by describing the geography and behavior of the fire, and by outlining his crew's tactics for managing it. Dueitt predicted that the fires would continue burning unless and until a change in the weather brought at least 1.5 inches of rainfall to extinguish the flames. Next, Dueitt discussed the evacuation orders for residents living near the fires. After his presentation, Dueitt invited the audience to ask questions.

The first question from an audience member was, "How can we support you?"

Dueitt responded, "Coming to this community meeting [is supporting us]. Give money to the fire departments - this is the best way....Best thing you can do is help us spread accurate information [about the fire]."

Another audience member shouted out to Dueitt, "We have been praying for you."

Dueitt responded, "Your prayers and support are felt.”

"This is the mountains," was the immediate response from another audience member.

The crowd of 200 people clapped in a show of their agreement with the man's comment, to affirm their caring spirit, and to bolster the extension of support from the audience towards the firefighters.

A seasoned firefighter from the United States Southwest who was assigned to the Tellico-Ferebee Fire reflected on the exchange between the firefighters and the community by saying, "I've fought fires all over the country for several decades now, and I've never felt this kind of community support anywhere. Southern hospitality is really coming through."

This senior firefighter's sentiments were echoed on November 13, 2016 in this message that was posted on "Boteler and Nantahala Branch Fires" Facebook account:

The welcome we have received in North Carolina has been far and above anything we've experienced elsewhere. The citizens have opened their hearts and welcomed us to the community as if we were long lost family. This welcome has gone a long way toward making us all feel more at home and has lessened the ache we feel being away from our loved ones. Thank you for showing us what "Southern Hospitality" means. You folks are the best (Boteler and Nantahala Branch Fires 2016).

The interpersonal connections made during the Tellico-Ferebee community meeting led to the formation of a novel collective consisting of mountain residents and professional wildland firefighters from both nearby and faraway. Some of the firefighters were permanent residents of the area with full-time positions working in the Nantahala-Pisgah National Forest. The fire crews also included people who traveled from 42 different states in the United States to work on the wildfires. The firefighters' respectful attitudes towards residents in the fire-affected areas was met by the residents' extension of 'Southern Hospitality' towards the wildland firefighters who temporarily occupied and protected their territory. In 
a particularly enthusiastic display, 580 flag-waving schoolchildren cheered for firefighters on November 19, 2016 as they returned to headquarters after their day shift working on the Tellico-Ferebee Fire.

As an outcome of the community meeting, the audience and the wildland firefighters entered each other's affective worlds.

The community who lives in the landscape affected by the Tellico-Ferebee Fire is merely one of many who established supportive relationships with wildland firefighter crews. Numerous Blue Ridge Mountain communities expressed their gratitude to wildland firefighting crews. Schoolchildren in Pickens County, South Carolina created handmade thank you cards for firefighters working on the Pinnacle Mountain Fire. Across the region, residents displayed large thank you banners on churches, businesses, and community centers. They also donated money, food, and gear to IMTs and local fire departments, and volunteered in cafeterias and incident command posts. Wildland firefighters and mountain communities entered each other's affective worlds as an outcome of their various fire-driven interactions. These activities were manifestations of the relationships between people, fire, and place.

\section{Different Interest Groups with Varied Interpreta- tions of Fire Effects on Blue Ridge Ecosystems}

In the wake of the fall 2016 wildfires, numerous interest groups expressed their opinions about the effects of fire in Blue Ridge Mountain ecosystems. Two processes became apparent as interest groups developed their interpretations of the postfire landscape. First, each interest group brought specific assumptions about the fire ecology of the Southern Appalachians to their endeavors to observe the wildfires' effects. One group, the Sanctuary Guild ${ }^{4}$, was of the opinion that the wildfires negatively affected Appalachian ecosystems. Another group, Blue Vision, approached a postfire site with the hypothesis that fire benefitted Appalachian ecosystems. Both the Sanctuary Guild and Blue Vision selected acidic cove ecosystems (though these were two different coves) as places to search for information about the fires' effects. Both organizations chose mid-April as the time for their searches. Both NGOs especially sought to observe native spring ephemerals in acidic cove ecosystems as the means for determining whether or not the forests would recover from the wildfires. Second, each group found the evidence they needed to support their hypotheses.

To illustrate the ways the Blue Ridge Complex validated both a fire-is-good ethic and a fire-is-bad ethic, I describe two group hikes that traveled through areas that were burned by Blue Ridge Complex fires. Although these are strongly contrasting environmental ethics, the postfire Blue Ridge landscape accommodated both sets of understandings about the roles of fire in the Southern Appalachians. The first group hike I describe is a hike in the site of the Rock Mountain Fire hosted by the Sanctuary Guild, a national nonprofit conservation organization (NGO). The second hike I describe is in the site of the TellicoFerebee Fire hosted by the regional NGO Blue Vision. Both hikes occurred early in the growing season that followed the fall fire season, and both were billed as opportunities to witness the effects of wildfires on the wildflowers that are popular among the region's residents.

Sanctuary Guild: One Group's Interpretation of Fires' Effects on an Appalachian Acidic Cove Forest

On April 19, 2017, the Sanctuary Guild led an excursion they called "Flowers After Fires" to explore the early spring plant life in the wake of the humancaused Rock Mountain Fire, which burned acres 24,725 acres (12,962 in Georgia and 11,763 in North Carolina) between November 9th and December 15th, 2016. The Sanctuary Guild's two hike leaders, Franklin and Brook, approached the burned Southern Nantahala Wilderness with the hypothesis that fire is detrimental to Appalachian acidic cove ecosystems like the one traversed during this hike. In leading community members on the hike, the Sanctuary Guild was aiming to provoke them to question the "fire-isgood" platform promoted by the United States Forest Service who governs the Southern Nantahala Wilderness and the Nantahala and Chattahoochee National Forests that surround the Wilderness. The Sanctuary Guild's understanding of Southern Appalachian fire ecology is an alternative to the federal land managers' platforms and is a critical assessment of, in Franklin's words, the "narrative that prescribed fire is good" for these forests.

As the group of hikers gathered in a circle at the Deep Gap trailhead, Franklin asked everyone to introduce themselves. After a round of introductions, Franklin framed the hike in the location of the Rock Mountain Fire as one instance in the larger category of human-caused disturbances in wilderness areas. He 


\section{(f) Ethnobiolocy Letters \\ Research Communications
Special Issue on Ethics in Ethnobiology}

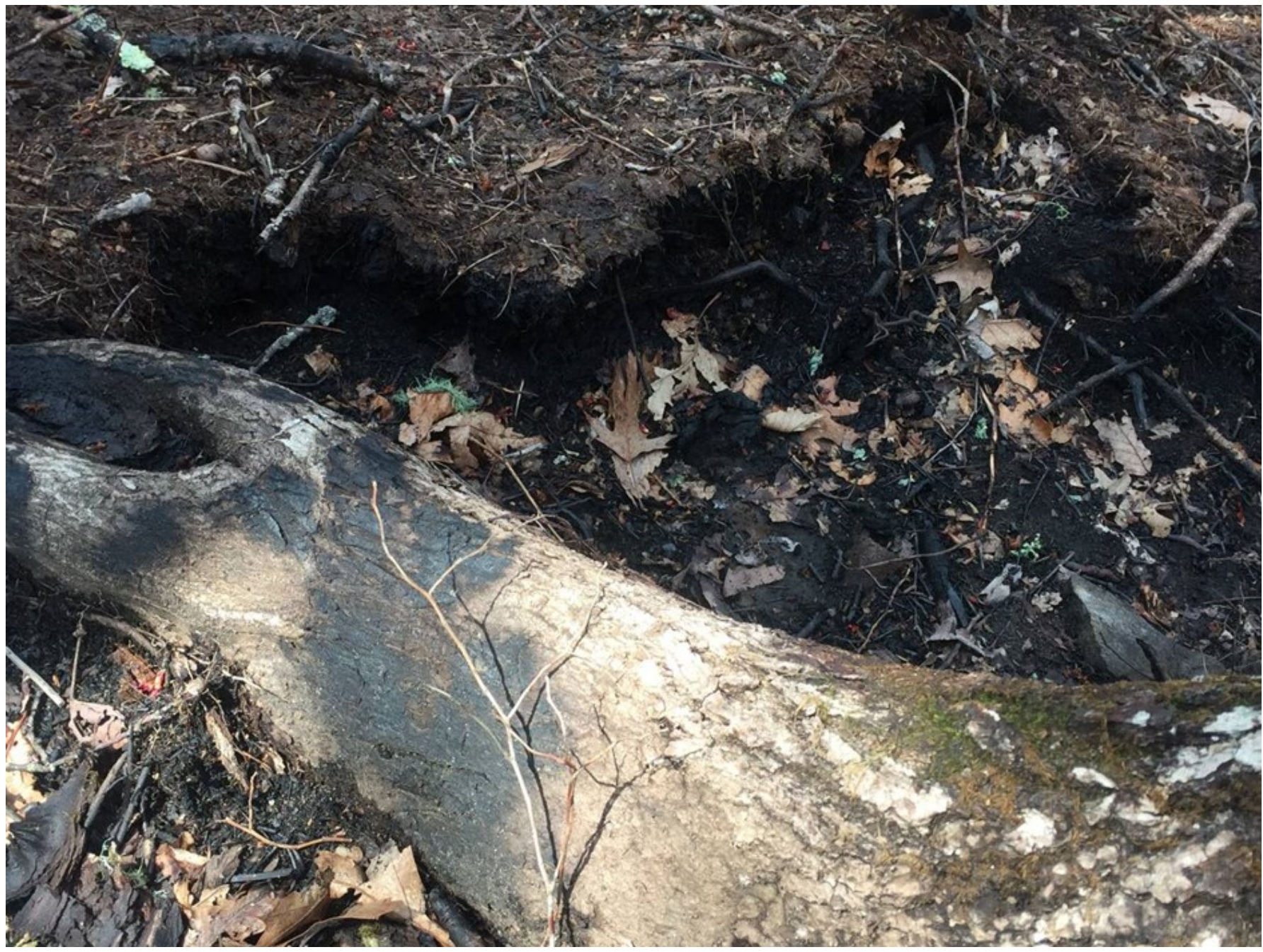

Figure 1 A deep hole burned by the Rock Mountain Fire in the organic duff layer, April 19, 2017. Photo by Cynthia Fowler.

hinted to the hikers that he felt that fire and other types of disturbance negatively impacted Southern Appalachian forests, yet he stated that his opinion was incompletely formulated. Whether wildfire or prescribed fire, Franklin said, "There are more questions than answers. We don't know what the effects [of the Rock Mountain Fire] are. The narrative has been that prescribed burning is good. But we don't really know."

Then, Franklin said, "Let's go see what we find," and he led the group out of the parking lot and onto the Appalachian Trail for a 2.65-mile hike to the summit of Standing Indian Mountain.

Along the course of the hike, Franklin and Brook pointed out evidence to support a hypothesis that fire has negative effects on the wilderness in the form of signs of soil erosion; fewer ephemerals than they had

.




\section{Research Communications

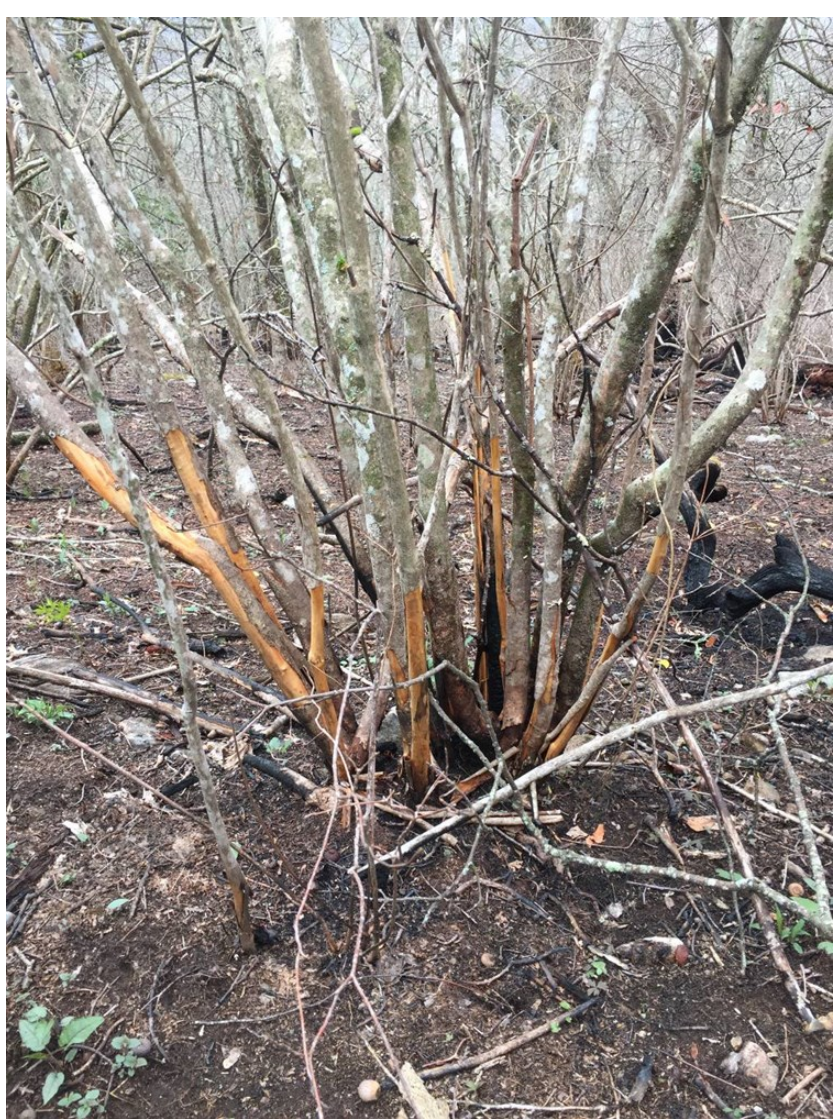

Figure 2 Acer rubrum showing fresh scars from the Rock Mountain Fire, April 19, 2017. Photo by Cynthia Fowler.

species has thin bark. He added, "I would be surprised if it survives a year."

The hikers passed by numerous Acer rubrum whose lower trunks had been scorched in the wildfire (Figure 2). Brook noticed, "scarring at their base." He predicted, "we will probably see tree mortality [in their future]." The thin bark of Acer rubrum indicates that the species does not tolerate fire well. Even though the specimens here in the Rock Mountain Fire site are starting to leaf out as they normally do in midApril, Brook expects the longer-term effects of the fire to be that red maple becomes, "less dominant relative to [the more fire tolerant] oaks."

Brook observed, "TThe fire] killed the flame azaleas. They are all dead above the ground."

Part way into the hike, the group paused near a fragmented stretch of bluets (Figure 3) to listen to Brook's interpretations of this population of spring ephemerals. Brook said, "This bluet population is affected. Bluets usually grow in big mats. Here in the burn, they only appear in areas where the moss didn't burn. This is definitely because of the fire's effects."

While they were gazing at the bluets, one of the hikers responded to the Brook's comment by saying, "It [the Rock Mountain fire] was coming [towards my house] from both directions. That is what was so upsetting."

This hiker conceptually connected the experiences she had while the fire was burning with her observations five months later of the fire's effects on vegetation. For this hiker, the wildfire was responsible for both the sparseness of the bluets and the threats to her own wellbeing. She used the group's observations of the bluets' growing habits as an opportunity to describe one aspect of her relationship to not only wildflowers but also more generally to fire and to the spaces affected by them. The botanical world was causing her to reflect on her personal, and very human, vulnerabilities. For the hike leaders, the ephemeral clues they found in the Southern Nantahala Wilderness confirmed what they had feared; namely, that wildfires negatively affect acidic cove ecosystems.

The Sanctuary Guild's hike leaders were reassured by the harm they witnessed in the biodiverse, mesic, deciduous forest. They found that fire negatively affected all of the cove forest's strata: its trees, shrubs, herbs, and soils. Fortunately, the Rock Mountain Fire behaved in such a way as to create a mosaic patch pattern that scorched some spots, mildly burned other spots, and skipped yet other locales. In the latter "safe zones," as Franklin called them, the forest floor (Figure 4) was carpeted with ramps (Allium tricoccum), trout lily (Erythronium sp.), and toothwort (Cardamine sp.). To explain the growth of a vibrant cluster of squaw root (Conopholis americana) (Figure 5) Brook said, "It's in a really good spot." Franklin and Brook concluded that the wildfire had harmed this beloved wilderness despite the contrary evidence that took form in a brilliant array of spring ephemerals.

Blue Vision: An Alternative Interpretation of Fires' Effects on the Wesser Creek. Acidic Cove Forest

The Blue Vision hike called "Flowers, Fires, Forests" that took place on April 15, 2017 was, like the "Flowers After Fires" hike, designed by an NGO to observe a wildfire's effects on the early spring plants that emerged after the previous season's wildfires. The hikers who participated in Blue Vision's event walked two miles of the Wesser Creek Trail, which is in the Nantahala National Forest. Between November $3^{\text {rd }}$ 


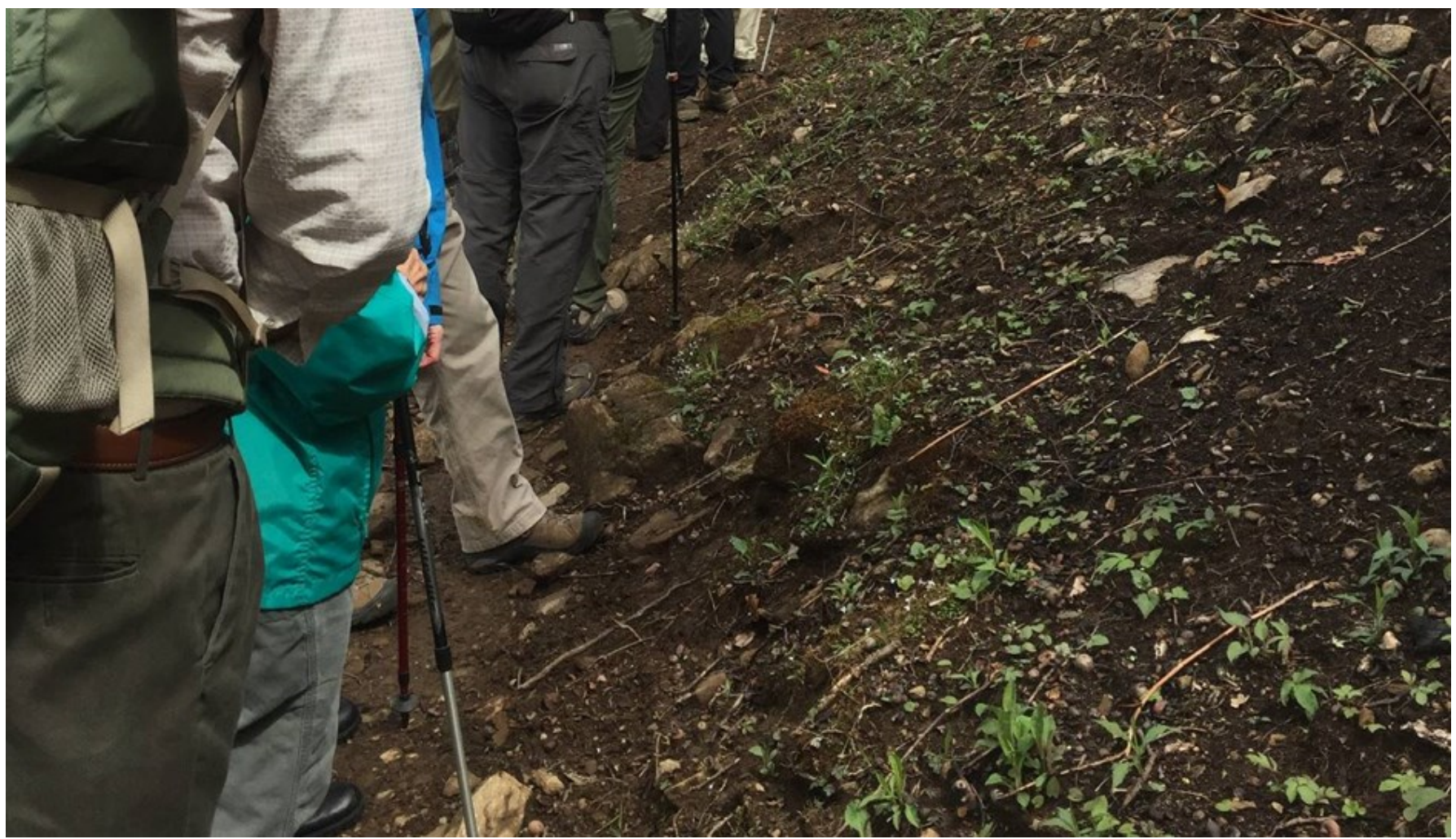

Figure 3 Hikers considering the postfire emergence of Houstonia sp., April 19, 2017. Photo by Cynthia Fowler.

and December $15^{\text {th }}, 2016$, the human-caused TellicoFerebee Fire burned 13,874 acres surrounding Wesser Creek (Figure 6). The Tellico- Ferebee Fire was so difficult to control that the United States Forest Service closed Wesser Creek Trail in November and evacuated residents in several nearby communities.

The leaders of the hike through the TellicoFerebee burn site were Elijah and Jeremiah, a field biologist and an ecologist, respectively, who both work for Blue Vision. Elijah and Jeremiah approached the postfire landscape with the idea that fire has the potential to benefit forests. Elijah shared his understanding of fire with the hikers at the beginning of the event when one of the female hikers asked Elijah, "The wildfires were incredibly destructive, weren't they?"

Elijah responded, "Well...I have a pretty long term view about fire." Without directly disagreeing with this the woman, Elijah offered her a story about the fire history of the region. In his story, fires periodically burned through Blue Ridge landscapes during the pre-colonial and colonial eras until the early twentieth century when misguided land managers vilified and subsequently excluded fires from the forests.
"People started putting out all the fires around here," Elijah said, and the forest's ecology began to change for the worse. The moral of Elijah's story was that the Blue Ridge Complex rightly reintroduced fire as a necessary mechanism for restoring healthy ecosystems to the region.

As members of Blue Vision's constituency, the hikers looked to the NGO's staff to learn how to perceive fire's effects in the Wesser Creek watershed. The participants in the Blue Vision event were as eager to walk in the woods as they were to observe the emerging wildflowers. Jeremiah periodically paused to observe and describe the vegetation as he guided the line of hikers up Wesser Creek Trail. Together they paused to admire approximately 40 species of herbs, shrubs, and trees. The hikers interpreted the high number of species as support for their idea that fire promotes biodiversity. The hiking group noticed the scorch marks inflicted by the fire on several native plants. Beech trees (Fagus grandifolia) and black birch (Betula lenta) appeared to be languishing due to the severity of the wildfire as it blew through the riparian cove.

"These trees are cooked," said Jeremiah as he studied the roots of several beech trees. 


\section{Research Communications

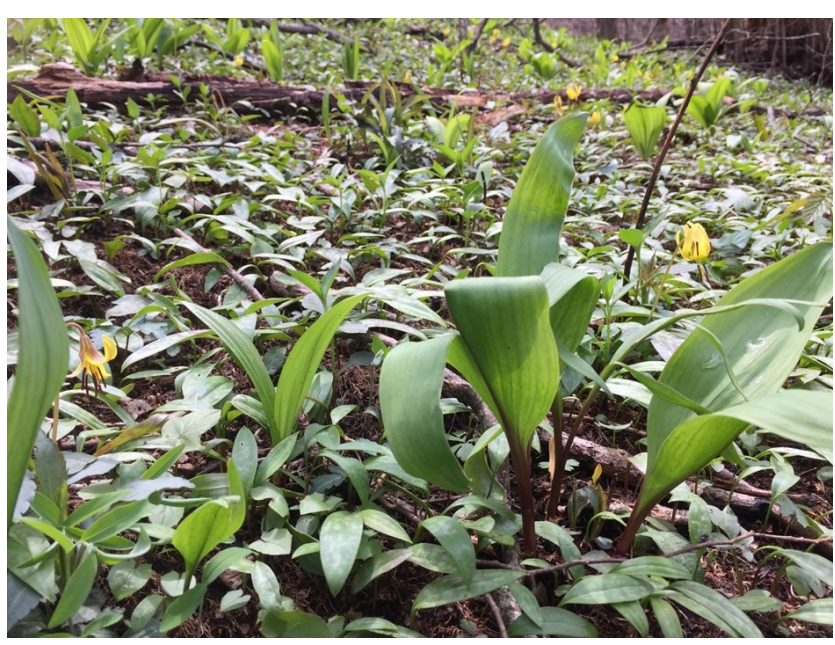

Figure 4 Ramps (Allium tricoccum), trout lily (Erythronium sp.), and toothwort (Cardamine sp.) growing in the Rock Mountain Fire site, April 19, 2017. Photo by Cynthia Fowler.

Similarly, in noticing the burned roots of black birch trees, Jeremiah said, "They may not have survived."

Using evidence from two separate species, Jeremiah eventually observed that, "Fire discriminates against small trees."

Also scorched by the wildfire were numerous specimens of the two Ericaceous shrubs dog hobble (Leucothoe fontanesiana) and rhododendron (Rhododendron sp.). For the latter shrub, Elijah interpreted the effects of fire as good for biodiversity.

According to Elijah,

One hundred years ago, there would have been much less rhododendron. Dead rhododendron will open the forest floor to light [thereby creating more favorable conditions for the germination of multiple other species]. Rhododendron is bad for diversity.

Elijah's conclusions about the fire sensitivity of two shrub species and Jeremiah's conclusions about the fire intolerance of two tree species did not add up to an overall anti-fire conclusion from them. Elijah and Jeremiah brought to the hike with them the opinion that fire has positive effects on Blue Ridge forests, and they interpreted the flora that was emerging merely four months after the TellicoFerebee Fire within this frame. Individual hikers also came to Blue Vision's event with presumptions about the ecology of the place and the role of fire there.
Elijah and Jeremiah drew on fire ecology to define their own and their organization's environmental ethics. This is similar to the way Franklin and Brook articulated their ethics by immersing themselves and their constituents in the site of the Blue Ridge Complex. The two organization's understandings of fire contrast with one another: Blue Vision promoted a fire-is-good platform and the Sanctuary Guild advocated a fire-is-bad stance. What is similar about both organizations is that they were able to find evidence to support their positions even while citing postfire phenomenon in acidic cove forests. Yet, the contrasting opinions have very different implications for how people relate to fire and to the environment.

\section{Discussion}

The postfire hikers on both the Sanctuary Guild and Blue Vision's excursions formulated their positions in spaces they had only recently come to understand as flammable. The hikers combined their experiences while the fires were active with new experiences acquired while moving through the burned forests abloom with spring ephemerals yet still marked with char from the previous season's wildfire. Their emerging understandings of the wildfires' effects in the Blue Ridge bioregion were negotiated in conversation with one another, and were influenced by their NGO guides. A particular environmental ethic, constructed as an effect of the fire, emerged among both the Sanctuary Guild and Blue Vision hikers.

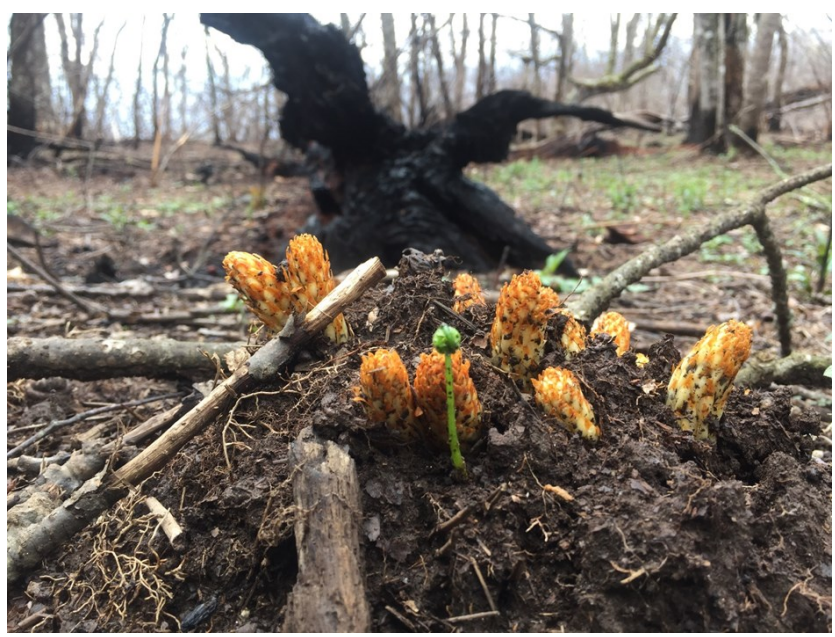

Figure 5 Squaw root (Conopholis americana) thriving in a "Safe Zone" in the spring after the Rock Mountain Fire, April 19, 2017. Photo by Cynthia Fowler. 


\section{Et Ethnobiolocy Letters

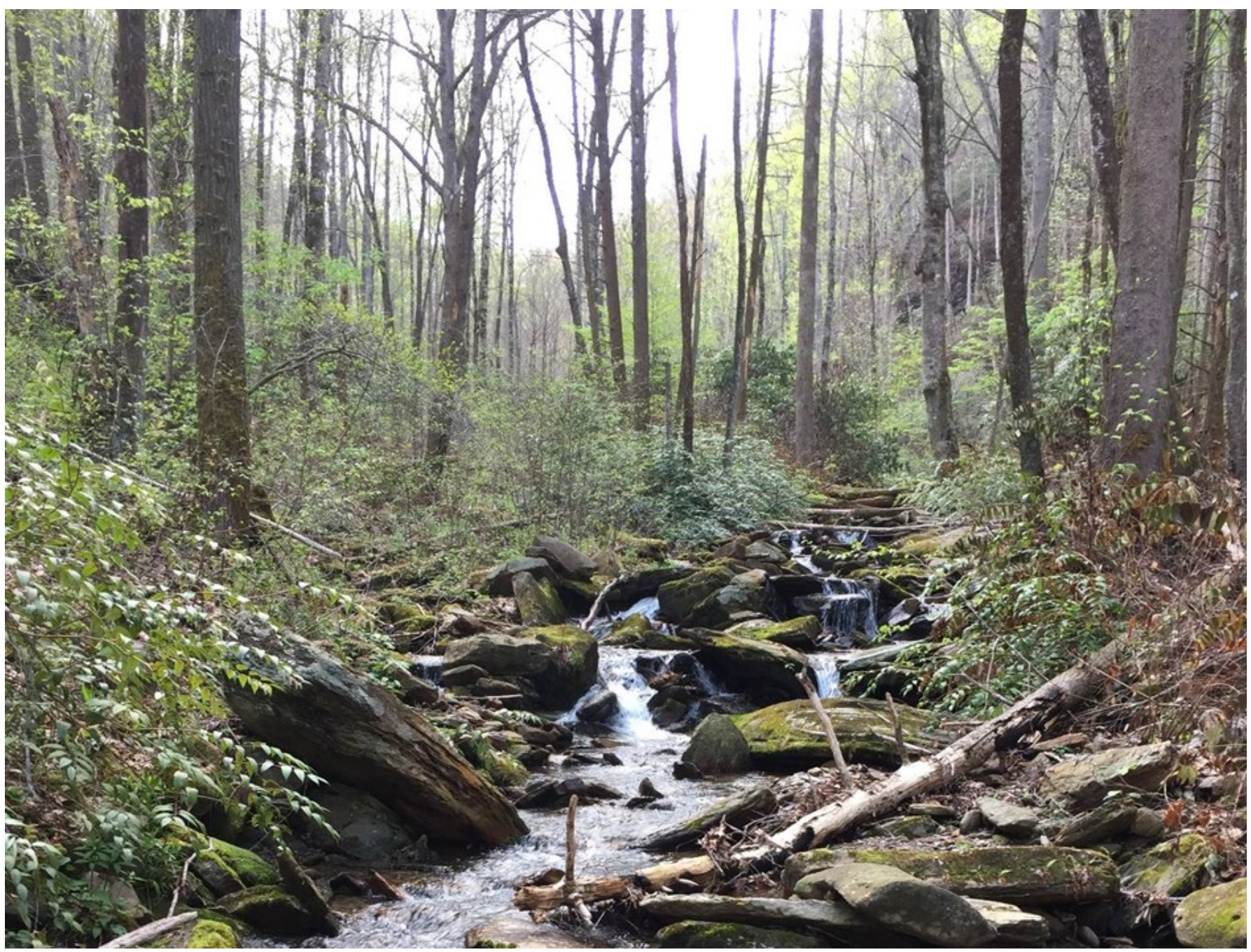

Figure 6 Wesser Creek in Nantahala National Forest, North Carolina, April 15, 2016. Photo by Cynthia Fowler.

This article has recounted the ways in which a seasonal proliferation of wildfires that provoked curiosity about their long-term effects generated occasions for people to formulate their values related to other people, to fire, and to the environment. The Blue Ridge Complex spurred residents of the bioregion to consider "how one should live and what kind of person one should be" (Keane 2015:20 quoted in Weiss 2017:2). The atmospheres the wildfires created while they were burning and long after they extinguished have been particularly productive for the construction of people's environmental ethics. Residents of the Blue Ridge province have experienced numerous moments of ethical reflection since the unusual fall 2016 wildfire season. The formation of environmental ethics takes place within biosocial contexts, at individual and collective levels, and in private and group settings. In conversations with others during community gatherings, people living in the Blue Ridge Complex zone produced a collective "heterogeneous, contingent, unstable, and partial" ethical assemblage for living in a burning and burned landscape (Collier and Ong 2005:12).

Wildfires exhibit great agency in prompting the reconfiguration of social groups and triggering community gatherings. Ethnographic evidence from community gatherings in the Blue Ridge Mountains demonstrates that wildfires inspire individuals and organizations to assemble for discussing fire and exploring landscapes. In these assemblies, people collectively construct their ethical lives in the processes of interacting with one another, nonhuman species, fire, smoke, and the myriad biosocial features 
of their ecosystems. A novel fire regime and a novel social formation co-emerged in WNC in the wake of the fall 2016 fire season.

\section{Notes}

${ }^{1} \mathrm{~A}$ fire complex is multiple fires grouped together so wildland firefighters can manage them through one Incident Command Team (ICT). In the fall of 2016, wildfires were burning across the Blue Ridge Physiographic Province, including in Western North Carolina, northwestern South Carolina, North Georgia, East Tennessee, and Virginia. The focus in this paper, however, is on only those fires that burned in Western North Carolina, northwestern South Carolina, and the portion of North Georgia where the Rock Mountain Fire burned. As a group, I refer to these wildfires in the Carolinas and Georgia as the Blue Ridge Complex.

${ }^{2}$ More wildfires burned in the earlier months of 2016 and additional incidents occurred in the winter and spring of 2017. In total, the pattern of wildfires constituted a full year-long fire season rather than the dual late-winter/early-spring and fall wildfire season that is more typical for the region.

${ }^{3}$ The Nantahala Branch Complex was a subset of the Blue Ridge Complex that included numerous fires in the Nantahala National Forest. The Nantahala Branch Complex was the most significant subset of fires during the fall of 2016 in the Blue Ridge Physiographic Province.

4"Sanctuary Guild" and "Blue Vision" are pseudonyms as are the names of individuals at their events.

\section{Acknowledgments}

The Blue Ridge Fire Complex project relied on the willingness of numerous organizations and many individuals who are concerned about the Southern Appalachian environment. I use pseudonyms in this paper to identify these organizations and individuals because of the ethical issues that I discuss herein. I hope that I have already and will in the future adequately compensate the organizations and individuals who go by pseudonyms here through participating in the community events they organize, doing community engagement and volunteer work, collaborating through educational events, and advocating for meaningful causes.

\section{Declarations}

Permissions: This article contains a combination of information collected in one-on-one interviews and information documented during open social gatherings. I obtained verbal consent from all individuals who donated their time for one-on-one interviews. I did not obtain verbal consent from other participants who attended the community gatherings where I collected information.

Sources of funding: None declared.

Conflicts of Interest: None declared.

\section{References Cited}

Boteler and Nantahala Branch Fires. 2016. The Welcome We Have Received in North Carolina [Facebook post]. Available at: https:// www.facebook.com/BotelerFire/. Accessed on November 27, 2017.

Chávez, K. Outbreak of WNC Wildfires Takes Toll on Wildlife, Environment [web page]. Available at: http://www.citizen-times.com/story/news / local/2016/11/18/outbreak-wnc-wildfires-takes-toll -wildlife-environment/93788956/. Accessed on February 25, 2018.

Collier, S. J., and A. Ong. 2005. Global Assemblages, Anthropological Problems. In Global Assemblages: Technology, Politics, and Ethics as Anthropological Problems, edited by A. Ong and S. J. Collier, pp. 321. Blackwell Publishing Ltd, Malden, MA.

Coughlan, M. R. 2016. Wildland Arson as Clandestine Resource Management: A Space-Time Permutation Analysis and Classification of Informal Fire Management Regimes in Georgia, USA. Environmental Management 57:1077-1087.

Cox, L. E., J. L. Hart, D. C. Dey, and C. J. Schweitzer. 2016. Composition, Structure, and Intra-Stand Spatial Patterns Along a Disturbance Severity Gradient in a Quercus Stand. Forest Ecology and Management 381:305-317.

Delcourt, P. A., and H. R. Delcourt. 2004. Prehistoric Native Americans and Ecological Change: Human Ecosystems in Eastern North America Since the Pleistocene. Cambridge University Press, Cambridge, United Kingdom.

Fowler, C., and E. Konopik. 2007. The History of Fire in the Southern United States. Human Ecology Review 14:165-176. 
Hendershot, D. A Perfect Storm or the New Norm? [web page]. Available at: http://www.smliv.com/ features/a-perfect-storm-or-the-new-norm/. Accessed February 25, 2018.

InciWeb. Incident Information System [web page]. Available at: https://inciweb.nwcg.gov/. Accessed February 25, 2018.

Keane, W. 2015. Ethical Life: Its Natural and Social Histories. Princeton University Press, Princeton, NJ.

USDA Forest Service. 2018. Collaboration and Public Involvement [web page]. Available at: https:// www.fs.usda.gov/main/planningrule/collaboration. Accessed on February 25, 2018.
Vayda, A. P. 2009. Explaining Human Actions and Environmental Changes. Altamira Press, Lanham, MD.

Weiss, J. Z. 2017. Ethics, Value, and Interaction: Bridging Natural and Social Histories in a Semiotic Framework [web page]. Available at: http:// www.anthropology-news.org/?book-review=ethicsvalue-and-interaction-bridging-natural-and-socialhistories-in-a-semiotic-framework. Accessed February 25, 2018. 